JURNAL PENDIDIKAN, p-ISSN 2715-095X, e-ISSN 2686-5041

Volume 29, No.3, Nopember 2020 (331-338)

Online: http://journal.univetbantara.ac.id/index.php/jp

\title{
Penerapan Model Pembelajaran Index Card Match untuk Meningkatkan Prestasi Belajar Pendidikan Jasmani, Olahraga dan Kesehatan Siswa Kelas IV SD Negeri Serut 02
}

\author{
Roni Kurniawan \\ Guru SD Negeri Serut 02 Kecamatan Nguter Kabupaten Sukoharjo \\ Email: ronikurniawan0881@gmail.com
}

\begin{abstract}
Abstrak: Tujuan penelitian ini adalah untuk meningkatkan prestasi belajar Pendidikan jasmani, olahraga dan kesehatan dengan model pembelajaran kooperatif tipe ICM pada siswa kelas IV SD Negeri Serut 02 semester I tahun pelajaran 2018/2019. Penelitian ini menggunakan metode Penelitian Tindakan Kelas yang meliputi perencanaan, tindakan, observasi dan refleksi. Subjek dalam penelitian ini adalah siswa IV SD Negeri Serut 02 semester I tahun pelajaran 2018/2019 yang berjumlah 8 siswa. Objek penelitian ini adalah prestasi belajar pendidikan jasmani, olahraga dan kesehatan siswa melalui model pembelajaran Index Card Match. Data dikumpulkan dengan menggunakan tes, observasi dan dokumentasi. Analisis data menggunakan teknik analisis deskriptif komparatif dengan persentase. Penelitian ini menunjukkan bahwa penerapan model pembelajaran kooperatif tipe Index Card Match dapat meningkatkan prestasi belajar pendidikan jasmani, olahraga dan kesehatan siswa hal ini ditujukkan dengan skor awal rata- rata prestasi belajar pendidikan jasmani, olahraga dan kesehatan siswa keadaan awal 73,12 meningkat pada siklus II menjadi 83,75. Dari segi persentase ketuntasan belajar siswa, keadaan awal 50\% meningkat pada siklus II menjadi $100 \%$.
\end{abstract}

Kata-kata Kunci: prestasi belajar pendidikan jasmani, olahraga dan kesehatan siswa, model pembelajaran kooperatif ICM.

\section{The Application of Index Card Match Learning Model to Improve the Achievement of Sport Physical and Healt Education in Grade IV Students}

\author{
Roni Kurniawan \\ The Teacher of SD Negeri Serut 02 Kecamatan Nguter Sukoharjo Regency \\ Email: ronikurniawan0881@gmail.com
}

\begin{abstract}
The purpose of this classroom action research is to improve students' learning achievement of Sport Physical and Healt Education through learning model of Index Card Match in grade IV students of semester 1 of SD Negeri Serut 02 in the 2019/2020 school year. This research was conducted from July to December 2019 in SD Negeri Serut 02. The subjects of this study were students of class IV as many as 32 students. This research is a Classroom Action Research conducted in two cycles. Data collection techniques used documentation, observation, and written tests. Data collection tools are observation sheets, test items, and value list documents. Data analysis using comparative descriptive analysis is followed by reflection on each cycle consists of four steps, namely: (1) Planning, (2) Action Implementation, (3) observation, and (4) reflection.The results of this study indicate an increase in learning achievement of Sport Physical and Healt Education Subject students. This can be seen from the average score of learning achievement of Sport Physical and Healt Education Subject students also experienced an increase before the action of 73.12 and on the second cycle of 83.75. In addition, the percentage of students' learning mastery, example before the action of $50 \%$ and in the second cycle of $100 \%$.
\end{abstract}


Keywords: Learning Achievement of Sport Physical and Healt Education, Learning Model of Index Card Match

\section{Pendahuluan}

Upaya peningkatan prestasi belajar tersebut antara lain dengan menggunakan metode pembelajaran yang beragam dalam proses kegiatan belajar mengajar, karena metode mengajar yang digunakan guru akan sangat berpengaruh terhadap cara belajar peserta didik. Setiap peserta didik memiliki cara belajar yang berbeda-beda. Metodologi mengajar dalam dunia pendidikan perlu dimiliki oleh pendidik, karena keberhasilan Proses Belajar Mengajar (PBM) bergantung pada metode mengajar gurunya. Jika cara mengajar gurunya disukai oleh siswa, maka siswa akan tekun, rajin, antusias menerima pelajaran yang diberikan, sehingga diharapkan akan terjadi perubahan tingkah laku pada siswa baik tutur katanya, sopan santunnya, motorik dan gaya hidup. Berdasarkan hasil pengamatan di di kelas IV SD Negeri Serut 02, diketahui bahwa masalah yang di hadapi oleh siswa adalah masih rendahnya prestasi belajar yang dimiliki oleh siswa terutama pada pelajaran Pendidikan jasmani, olahraga dan kesehatan. Hal ini dapat dilihat dari nilai ulangan harian Pendidikan jasmani, olahraga dan kesehatan materi menerapkan budaya hidup sehat, dengan KKM sebesar 75,0 diperoleh rata-rata nilai ulangan adalah 69,2 dan persentase ketuntasan adalah 50\% (4 siswa). Masalah itu disebabkan karena rendahnya minat belajar siswa pada mata pelajaran Pendidikan jasmani, olahraga dan kesehatan. Kebanyakan siswa menganggap Pendidikan jasmani, olahraga dan kesehatan itu sepele untuk dipelajari, sehingga menurut mereka Pendidikan jasmani, olahraga dan kesehatan adalah pelajaran yang tidak penting dan tidak terpakai. Selain itu metode yang di gunakan dalam proses pembelajaran masih menerapkan metode konvensional atau ceramah. Salah satu alternatif yang dapat ditempuh untuk meningkatkan prestasi siswa adalah melalui kreatifitas guru dalam memilih metode mengajar. Semua metode pengajaran belum tentu cocok untuk setiap pokok bahasan yang ada, maka pelaksanaan metode mengajar harus tepat sesuai dengan topik pelajaran dan sub pokok bahasan yang disajikan sehingga proses pengajaran akan menjadi lebih efektif dan efisien. Metode pembelajaran yang dapat menarik minat siswa dalam belajar contohnya adalah dengan penerapan Metode Pembelajaran Index Card Match. Prestasi belajar adalah hasil belajar yang dicapai siswa dalam proses belajar mengajar sehingga terdapat proses perubahan dalam pemikiran dan tingkah laku. A.Tabrani Rusyan (2010:7) mengemukakan pendapatnya sebagai berikut : "Prestasi belajar yang dicapai seseorang individu merupakan hasil interaksi antara berbagai faktor yang mempengaruhi baik dari dalam (faktor internal) maupun faktor dari luar (eksternal ) individu". Dari pendapat di atas dapat disimpulkan prestasi adalah hasil yang dilakukan/dikerjakan untuk mendapatkan kepandaian. Prestasi adalah bukti / hasil usaha yang dicapai setelah melakukan usahanya sebaik mungkin. Pembelajaran aktif tipe Index Card Match (Hisyam Zaini, Bermawy Munthe, Sekar Ayu Aryani, 2008: xiv) digunakan pendidik dengan maksud mengajak peserta didik untuk menemukan jawaban yang cocok dengan pertanyaan yang sudah disiapkan.

Langkah-langkah Penerapan metode Index Card Match (Hisam Zaini, Bermawy Munthe, Sekar Ayu Aryani, 2008:67-68), adapun langkah-langkah pembelajaran dengan metode ini adalah sebagai berikut. (1) Buatlah potongan-potongan kertas sebanyak jumlah 
siswa yang ada di dalam kelas. (2) Bagilah kertas-kertas tersebut menjadi dua bagian yang sama. (3) Pada separuh bagian, tulis pertanyaan tentang materi yang akan dibelajarkan. Setiap kertas berisi satu pertanyaan. (3) Pada separuh kertas yang lain, tulis jawaban dari pertanyaan-pertanyaan yang telah dibuat. (4) Kocoklah semua kertas sehingga akan tercampur antara soal dan jawaban. (5) Setiap siswa diberi satu kertas. Jelaskan bahwa ini adalah aktivitas yang dilakukan berpasangan, separuh siswa akan mendapatkan soal dan separuh yang lain akan mendapatkan jawaban. (6) Mintalah kepada siswa untuk menemukan pasangan mereka. Jika ada yang sudah menemukan pasangan, mintaklah kepada mereka untuk duduk berdekatan. Jelaskan juga agar mereka tidak memberitahu materi yang mereka dapatkan kepada teman yang lain. (7) Setelah semua siswa menemuakn pasangan dan duduk berdekatan, mintalah kepada setiap siswa bergantian untuk membacakan soal yang diperoleh dengan kertas kepada teman-temannya yang lain. Selanjutnya soal tersebut dijawab oleh pasangannya. (8) Akhir proses ini dengan membuat klarifikasi dan kesimpulan. Berdasarkan latar belakang masalah di atas, permasalahan yang diajukan dalam penelitian ini adalah "Apakah model pembelajaran Index Card Match dapat meningkatkan kemampuan prestasi belajar Pendidikan jasmani, olahraga dan kesehatan siswa kelas IV SD Negeri Serut 02 semester 1 tahun pelajaran 2018/2019?'. Tujuan dari penelitian ini adalah untuk meningkatkan prestasi belajar Pendidikan jasmani, olahraga dan kesehatan dengan model pembelajaran Index Card Match pada siswa kelas IV SD Negeri Serut 02 semester 1 tahun pelajaran 2018/2019.

\section{Metode Penelitian}

Penelitian ini adalah Penelitian Tindakan Kelas (PTK), merupakan suatu pencermatan terhadap kegiatan yang sengaja dimunculkan, dan terjadi dalam sebuah kelas (Arikunto, 2010: 130). Penelitian ini dilaksanakan di SD Negeri Serut 02. Tahap-tahap pelaksanaan kegiatan dilakukan selama kurang lebih lima bulan yaitu sejak bulan Agustus sampai dengan bulan November 2018. Subjek penelitian tindakan kelas ini adalah siswa kelas IV SD Negeri Serut 02 Tahun pelajaran 2018/2019 yang berjumlah sebanyak 8 siswa yang terdiri dari 4 siswa laki-laki dan 4 siswa perempuan, sebagai subjekpenerima tindakan, sedangkan untuk subjekpelaku tindakan adalah guru Pendidikan Jasmani, Olahraga dan Kesehatan kelas IV selaku guru, teman sejawat selaku subjekyang melakukan observasi proses pembelajaran, Kepala Sekolah selaku subjeksumber data. Metode pengumpulan data dilakukan melalui teknik tes, observasi dan dokumentasi. Teknik pengumpulan data yang digunakan adalah: (a) Tes, observasi, dan dokumentasi. Metode tes digunakan untuk memperoleh data tentang prestasi belajar Pendidikan Jasmani, Olahraga dan Kesehatan siswa sebelum penelitian, selama penelitian dan setelah penelitian dilaksanakan.Observasi yang digunakan adalah observasi sistematis, yaitu observasi yang dilakukan oleh pengamat dengan menggunakan pedoman sebagai instrumen pengamatan. Instrumen yang digunakan dalam penelitian ini adalah: lembar observasi, tes, dan dokumentasi. Lembar observasi dugunakan peneliti sebagai pedoman melakukan observasi atau pengamatan guna memperoleh data yang akurat dalam pengamatan. Lembar observasi juga digunakan untuk memonitor dan mengevaluasi setiap tindakan agar kegiatan observasi tidak terlepas dari konteks permasalahan dan tujuan penelitian. Tes digunakan untuk melihat seberapa besar penguasaan konsep Pendidikan Jasmani, Olahraga dan Kesehatan siswa terhadap materi yang diajarkan. Hasil tes dianalisis guna mengetahui penguasaan materi Pendidikan Jasmani, Olahraga dan Kesehatan setelah dilakukan model pembelajaran ICM.Indikator keberhasilan dalam penelitian ini adalah apabila nilai rata-rata tes siswa sekurang- 
kurangnya 80,0 dan banyak siswa dengan nilai di atas batas ketuntasan minimal (KKM) yaitu $\geq 75,0$ mencapai $\geq 90 \%$.

\section{Hasil Penelitian}

Berdasarkan hasil pretest, dari 8 siswa yang mencapai nilai KKM yaitu 75 sebanyak 4 siswa (50\%) dan siswa yang tidak mencapai nilai KKM sebanyak 4 siswa (50\%) dengan nilai rata-rata kelas sebesar 73,12. Guru hanya menerapkan modelceramah dan siswa hanya disuruh mendengarkan dan mencatat apa yang diperlukan. Hasil ini dapat ditampilkan pada grafik berikut.

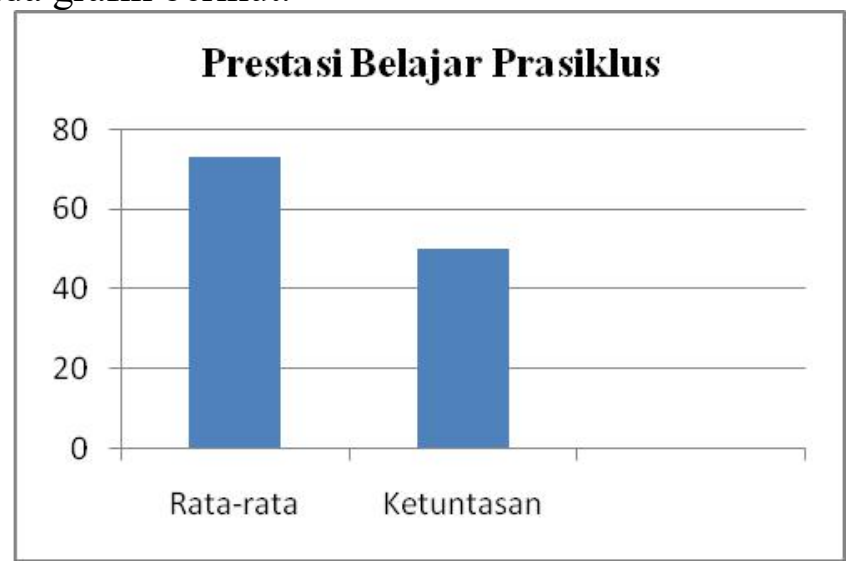

Gambar 1. Grafik Prestasi belajar Pendidikan Jasmani, Olahraga dan Kesehatan Siswa pada Prasiklus

Salah satu solusi yang dikembangkan adalah penggunaan modelpembelajaran kooperatif tipe ICM. Dengan penggunaan model pembelajaran tersebut diharapkan akan menciptakan suasana belajar yang berbeda, bervariasi dan menyenangkan sehingga dapat menarikperhatian siswa dan meningkatkan prestasi belajar siswa. Dalam siklus I terdapat 2 jam pelajaran (1 kali pertemuan), yaitu hari Rabu, 19 September 2018 jam ke1 dan 2 (pukul 09.25-10.45 WIB). Pertemuan pertama digunakan untuk pelaksanaan pembelajaran siklus I, pertemuan kedua digunakan untuk postest siklus I. Pelaksanaan proses belajar Pendidikan jasmani, olahraga dan kesehatan di kelas IV semester I SD Negeri Serut 02 yang bertujuan untuk meningkatkan prestasi belajar Pendidikan jasmani, olahraga dan kesehatan materi menerapkan budaya hidup sehatsiswa pada siklus I adalah sebagai berikut. Guru menyampaikan materi pembelajaran secara garis besar, menerapkan dan memberikan contoh soal, serta memberikan motivasi kepada siswa untuk mempelajari materi menerapkan budaya hidup sehat, dengan indikator menjaga kebersihan lingkungan rumah dan sekolah agar dalam proses pembelajaran selalu rajin dan aktif dalam mengikuti pelajaran. Guru membagi siswa menjadi 2 kelompok sesuai dengan nilai tengah semester yang digolongkan dengan kemampuan tinggi, sedang dan rendah. Kelas IV terdiri dari 8 siswa, sehingga setiap kelompok beranggotakan 4 siswa. Guru menempatkan siswa sesuai kelompoknya. Guru memberikan soal latihan disertai kartu soal dan jawab yang harus dikerjakan oleh setiap kelompok.Di sini guru hanya memimpin dan mengarahkan siswa dalam pembelajaran kelompok, guru tidak berperan aktif, karena guru berperan sebagai 
motivator dan fasilitator.Guru berkeliling dan membimbing siswa, memberikan beberapa bantuan secara terbatas kepada kelompok yang benar-benar kurang memahami materi.

Setelah tugas kelompok selesai dikerjakan, maka salah satu dari anggota kelompok harus berebut untuk mempresentasikan jawaban di depan kelas.Hal ini bertujuan untuk mengetahui sejauh mana pemahaman siswa mengenai materi yang disampaikan sekaligus untuk mengetahui jawaban setiap kelompok sudah tepat atau belum. Kemudian guru mengevaluasi prestasi belajar kelompok pada pertemuan I. Proses pembelajaran telah selesai dilakukan. Guru dan pengamat mengevaluasi hasil pengamatan dan hasil kerja siswa baik kelompok maupun individu.Guru dan pengamat merefleksi hasil penelitian pada siklus I. Pada siklus I, dari 8 siswa yang mencapai nilai kriteria ketuntasan minimal (KKM) yaitu 75 sebanyak 6 siswa (75\%), siswa yang tidak mencapai nilai kriteria ketuntasan minimal (KKM) sebanyak 2 siswa (25\%) dengan nilai rata-rata kelas sebesar 78,87.

Tabel1.Perolehan Nilai Prestasi belajar Pendidikan jasmani, olahraga dan kesehatan SiklusI

\begin{tabular}{llll}
\hline No. & Ketuntasan & Jumlah & Persentase \\
\hline $1 . \quad$ Tuntas & 6 & $75 \%$ \\
\hline $2 . \quad$ Tidak tuntas & 2 & $25 \%$ \\
\hline Jumlah & 8 & $100 \%$ \\
\hline Nilai tertinggi & & 85 \\
\hline Nilai terendah & & 74 \\
\hline Rata-rata & & 78,87
\end{tabular}

Pada siklus I ini, beberapa siswa masih belum aktif dalam kelompoknya, masih berbicara sendiri. Hal ini dikarenakan anggota dalam satu kelompok terlalu banyak. Perolehan prestasi belajar Pendidikan jasmani, olahraga dan kesehatan siswa materi menerapkan budaya hidup sehat pada siklus I belum mencapai indikator kinerja penelitian, maka penelitian dilanjutkan pada siklus II. Keberhasilan yang dicapai setelah siklus I hanya sebagian siswa yang menunjukkan partisPendidikan jasmani, olahraga dan kesehatansi yang meningkat sementara siswa lainnya masih pasif. Refleksi terhadap faktor-faktor yang menjadi penyebab kurangnya partisPendidikan jasmani, olahraga dan kesehatansi siswa adalah: (1) Sebagian siswa belum bisa mengikuti langkah-langkah pembelajaran model pembelajaran kooperatif tipe ICM; (2) Kerjasama dalam kelompok berdiskusi belum maksimal; (3) Hanya siswa tertentu saja yang dapat memahami materi dan soal yang diberikan kepada setiap kelompok.

Dalam siklus II terdapat 2 jam pelajaran (1 kali pertemuan), yaitu hari Kamis, 4 Oktober 2017Jam ke 2 dan 3 (pukul 07.50-09.10 WIB).Pelaksanaan proses belajar Pendidikan jasmani, olahraga dan kesehatan di kelas IV semester I SD Negeri Serut 02 yang bertujuan untuk meningkatkan prestasi belajar Pendidikan jasmani, olahraga dan kesehatan materi menerapkan budaya hidup sehatsiswa pada siklus II adalah sebagai berikut: Guru menyampaikan materi pembelajaran secara garis besar tentang menerapkan budaya hidup sehat, serta memberikan motivasi kepada siswa untuk mempelajari materi Menyajikan data dalam bentuk tabel dan Diagram batang, garis dan lingkaran,agar dalam proses pembelajaran selalu rajin dan aktif dalam mengikuti pelajaran. Guru membagi siswa menjadi 4kelompok sesuai dengan nilai prasiklus (keadaan awal) yang digolongkan dengan kemampuan tinggi, sedang dan rendah. Kelas IV terdiri dari 8 siswa, sehingga setiap kelompok beranggotakan 2 siswa. Guru menempatkan siswa sesuai kelompoknya. Siswa diberi kesempatan untuk mempelajari materi pelajaran yang telah diberikan dengan satu kelompoknya dan membantu teman satu kelompok apabila ada yang kurang memahami 
materi yang dipelajari. Kemudian guru memberikan soal latihan disertai kartu soal dan jawab yang harus dikerjakan oleh setiap kelompok.Di sini guru hanya memimpin dan mengarahkan siswa dalam pembelajaran kelompok.guru tidak berperan aktif, karena guru berperan sebagai motivator dan fasilitator.Guru berkeliling dan membimbing siswa, memberikan beberapa bantuan secara terbatas kepada kelompok yang benar-benar kurang memahami materi. Setelah tugas kelompok selesai dikerjakan, maka salah satu dari anggota kelompok harus berebutmempresentasikan jawaban.Hal ini bertujuan untuk mengetahui sejauh mana pemahaman siswa mengenai materi yang disampaikan sekaligus untuk mengetahui jawaban setiap kelompok sudah tepat atau belum. Kemudian guru mengevaluasi prestasi belajar kelompok.

Tabel 2. Nilai Prestasi belajar Pendidikan jasmani, olahraga dan kesehatan pada Siklus II

\begin{tabular}{lll}
\hline No. $\quad$ Ketuntasan & Jumlah & \multicolumn{1}{c}{ Persentase } \\
\hline 1. $\quad$ Tuntas & 8 & $100 \%$ \\
\hline 2. Tidak tuntas & 0 & $0 \%$ \\
\hline Jumlah & 8 & $100 \%$ \\
\hline Nilai tertinggi & & 88 \\
\hline Nilai terendah & & 80 \\
\hline Rata-rata & 83,75 \\
\hline
\end{tabular}

Proses pembelajaran telah selesai dilakukan. Guru dan pengamat mengevaluasi hasil pengamatan dan hasil kerja siswa baik kelompok maupun individu.Guru dan pengamat merefleksi hasil penelitian pada siklus II. Pada siklus II, dari 8 siswa yang mencapai nilai kriteria ketuntasan minimal (KKM) yaitu 75 sebanyak 8 siswa (100\%), siswa yang tidak mencapai nilai kriteria ketuntasan minimal (KKM) sebanyak 0 siswa $(0 \%)$ dengan nilai rata-rata kelas sebesar 83,75. Pada siklus II ini siswa sudah aktif dalam pembelajaran dan perolehan prestasi belajar Pendidikan jasmani, olahraga dan kesehatan materi penjumlahan pecahan penyebut beda telah melampaui indikator kinerja penelitian. Sehingga penelitian berhenti pada siklus II, tidak dilanjutkan pada siklus berikutnya.

\section{Pembahasan}

Hal ini dapat dilihat dari hasil penelitian dari siklus pertama sampai dengan siklus ketiga dapat diringkaskan seperti terlihat pada tabel sebagai berikut:Hasil analisis evaluasi yang dilaksanakan pada setiap siklus diperoleh peningkatan prestasi belajar siswa.Hal ini dapat dilihat pada nilai rata-rata siswa dan persentase ketuntasan hasil belajar siswa pada setiap siklus yang mengalami peningkatan.

Tabel 3. Peningkatan Hasil Belajar Pra Siklus, Siklus I, dan Siklus II

\begin{tabular}{ccccccc}
\hline No & Faktor & Pra Siklus & Siklus I & Siklus II & Indikator & Ket \\
\hline 1 & $\begin{array}{c}\text { Rata-rata } \\
\text { kelas }\end{array}$ & 73,12 & 78,87 & 83,75 & $\geq 80,00$ & Tercapai \\
\hline 2 & $\begin{array}{c}\text { Ketuntasan } \\
\text { belajar }\end{array}$ & $50 \%$ & $75 \%$ & $100 \%$ & $\geq 80 \%$ & Tercapai \\
\hline
\end{tabular}




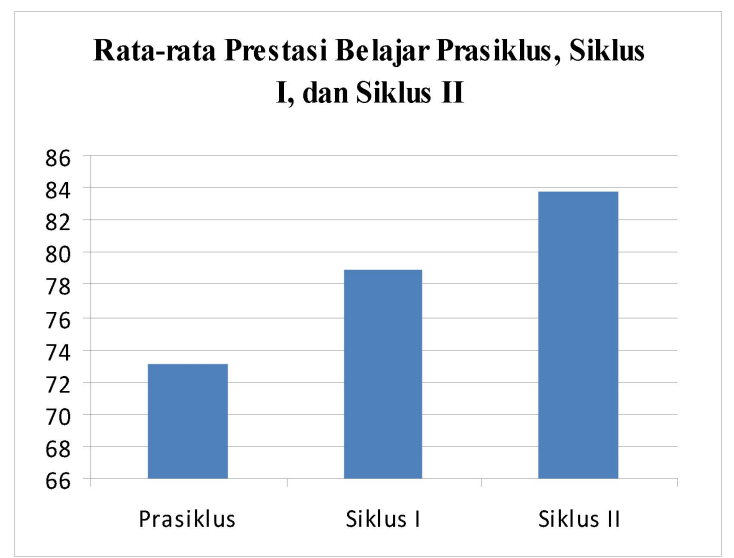

Gambar1. Grafik Perbandingan Rata-rata Prestasi Belajar Siswa

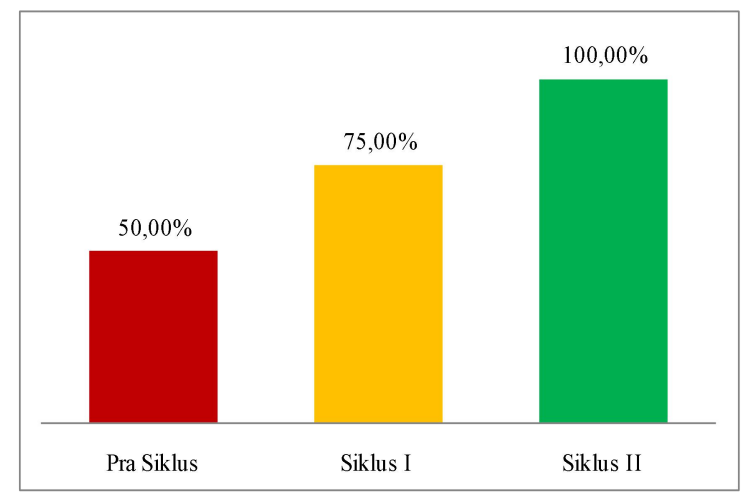

Gambar 2. Grafik Perbandingan Ketuntasan Belajar Siswa

Dari tabel dan grafik di atas dapat disimpulkan bahwa prestasi belajar Pendidikan Jasmani, Olahraga dan Kesehatan siswa dengan menerapkan model pembelajaran kooperatif tipe $I C M$ di setiap putaran mengalami peningkatan, yaitu: (1) Sebelum dilakukan tindakan, nilai rata-rata prestasi belajar siswa adalah 73,12 sedangkan persentase ketuntasan 65,52\%; (2) Setelah dilakukan tindakan pada siklus I, nilai rata-rata prestasi belajar Pendidikan Jasmani, Olahraga dan Kesehatan siswa mengalami peningkatan yaitu 78,87 dengan persentase ketuntasan $75 \%$, tetapi belum mencapai indikator yang diharapkan; (3) Pada siklus II, nilai prestasi belajar siswa meningkat yaitu menjadi 83,75 dengan persentase ketuntasan sebesar $100 \%$ dan sudah mencapai indikator yang diharapkan maka penelitian tindakan kelas ini sudah berhasil. Rata-rata prestasi belajar Pendidikan Jasmani, Olahraga dan Kesehatan siswa pada siklus II sebesar 83,75 $\geq 80,0$ (indikator kinerja) dan persentase ketuntasan siklus II sebesar $100 \% \geq 80 \%$ (indikator kinerja). Jadi, indikator kinerja sudah tercapai sehingga tidak dilanjutkan ke siklus berikutnya.

\section{Simpulan dan Saran}

Berdasarkan hasil penelitian tindakan kelas ini, maka dapat diambil kesimpulan sebagai berikut: "Model pembelajaran kooperatif tipe ICM dapat meningkatkan prestasi belajar Pendidikan Jasmani Olahraga dan Kesehatan siswa kelas IV SD Negeri Serut 02 semester I tahun pelajaran 2018/2019." Hal ini dapat dilihat dari persentase ketuntasan belajar siswa, yaitu: sebelum tindakan 4 siswa atau $50 \%$, pada siklus I sebanyak 6 siswa atau $75 \%$ dan pada siklus II sebanyak 8 siswa atau $100 \%$. Sedangkan rata-rata prestasi 
belajar Pendidikan Jasmani Olahraga dan Kesehatan siswa sebelum tindakan sebesar 73,12, pada siklus I sebesar 78,87, dan pada siklus II sebesar 83,75. Berdasarkan hasil penelitian tindakan kelas ini dapat diberikan saran sebagai berikut: (1) Pembelajaran kooperatif tipe ICM dapat diterapkan dalam pembelajaran Pendidikan Jasmani Olahraga dan Kesehatan untuk meningkatkan keaktifan siswa kelas IV pada materi menerapkan budaya hidup sehat. (2) Sebaiknya guru menguasai berbagai model pembelajaran agar siswa tidak merasa bosan dan enggan untuk belajar. (3) Perlu diadakan pembelajaran lebih lanjut dengan menggunakan model pembelajaran kooperatif tipe ICM pada materi lainnya.

\section{Daftar Rujukan}

Arikunto Suharsimi. (2006). Prosedur Penelitian Suatu Pendekatan Praktek. Jakarta : Rineka Cipta.

Hisyam Zaini, Bermawy Munthe, Sekar Ayu Aryani. (2008). Strategi Pembelajaran Aktif. Yogyakarta: Insan Mandiri

Tabrani Rusyan,dkk. (2010). Pendekatan dalam Proses Belajar Mengajar. Jakarta: Gramedia. 